\title{
'Florida Brilliance' Strawberry'
}

\author{
Vance Whitaker, Natalia A. Peres, and Shinsuke Agehara ${ }^{2}$
}

\section{Introduction}

'Florida Brilliance' (PPAF) is a new short-day strawberry cultivar released by the University of Florida and commercialized in 2018 . This cultivar was originally evaluated as breeding selection FL 13.26-134. It originated from a 2013 cross between breeding selection FL 11.31-14 (female parent) and selection FL 10-153 (male parent). 'Florida Brilliance' has been tested over several years at the University of Florida Gulf Coast Research and Education Center (GCREC) in Wimauma, FL, at the Florida Strawberry Growers Association (FSGA) headquarters in Dover, FL, and on several commercial farms.

The primary target of this publication is strawberry growers in west-central Florida, with a secondary audience of nursery growers who provide plants to Florida. Its main purpose is to describe important attributes of 'Florida Brilliance' and make management recommendations that will help growers obtain optimum performance from this cultivar. Because these descriptions and recommendations are specific to Florida, care should be taken in attempting to adapt them to other growing regions. Comparisons are made to 'Florida Radiance' (Chandler et al. 2009) (marketed as 'Florida Fortuna' outside the US and Canada), Sweet Sensation ${ }^{\circledR}$ 'Florida127' (Whitaker et al. 2015) (hereafter referred to as 'Florida127') and 'Florida Beauty' (Whitaker et al. 2017).

\section{Fruit and Plant Characteristics}

'Florida Brilliance' is so named for its attractive fruit, which are glossy and conical in shape (Figure 1). The gloss of the fruit is accentuated by the position of the achenes which are recessed below the fruit surface, creating curvatures that reflect light in many directions. This cultivar maintains a very consistent shape and does not produce any elongated fruit early in the season, which is a weakness of 'Florida Radiance' in Florida.

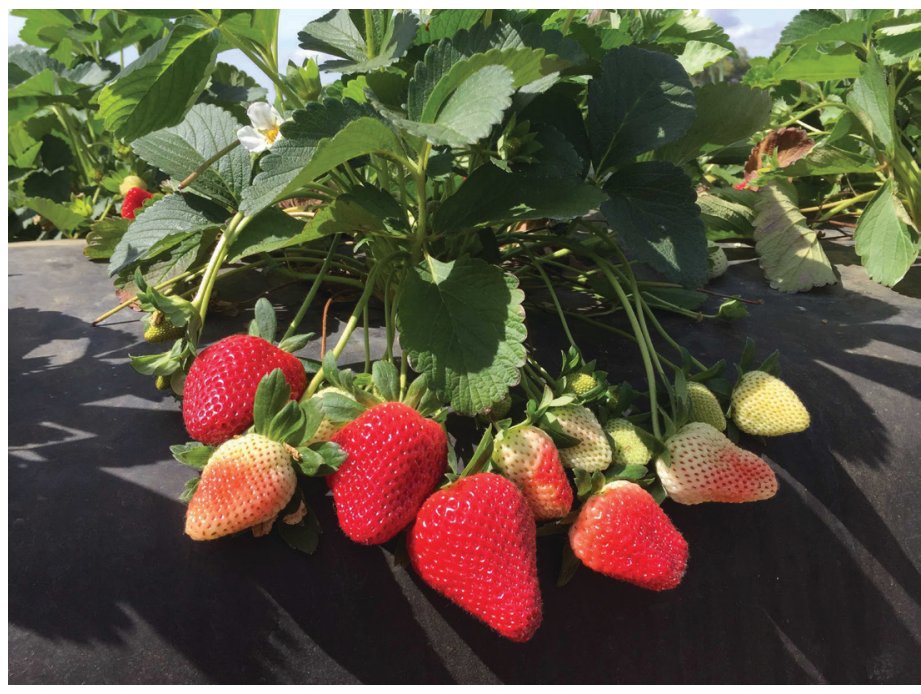

Figure 1. 'Florida Brilliance' on a commercial farm near Plant City, Florida in late February 2018.

Credits: Vance M. Whitaker, UF/IFAS

1. This document is HS1322, one of a series of the Horticultural Sciences Department, UF/IFAS Extension. Original publication date October 2018. Visit the EDIS website at https://edis.ifas.ufl.edu for the currently supported version of this publication.

2. Vance Whitaker, associate professor, Horticultural Sciences Department; Natalia A. Peres, professor, Department of Plant Pathology; and Shinsuke Agehara, assistant professor, Horticultural Sciences Department; UF/IFAS Gulf Coast Research and Education Center, Wimauma, FL 33598.

The use of trade names in this publication is solely for the purpose of providing specific information. UF/IFAS does not guarantee or warranty the products named, and references to them in this publication do not signify our approval to the exclusion of other products of suitable composition.

The Institute of Food and Agricultural Sciences (IFAS) is an Equal Opportunity Institution authorized to provide research, educational information and other services only to individuals and institutions that function with non-discrimination with respect to race, creed, color, religion, age, disability, sex, sexual orientation, marital status, national origin, political opinions or affiliations. For more information on obtaining other UF/IFAS Extension publications, contact your county's UF/IFAS Extension office. 
The fruit of 'Florida Brilliance' are firmer than other University of Florida cultivars, with excellent shelf life and juicy texture. The soluble solids content $\left({ }^{\circ} \mathrm{Brix}\right)$ of the fruit in central Florida ranges from $6 \%-9 \%$, depending on the harvest date, which is similar to 'Florida Radiance' and slightly lower than 'Florida Beauty' and 'Florida127. The titratable acidity is similar to or slightly lower than 'Florida Radiance', depending on the harvest date. Thus, its flavor has been rated slightly better than 'Florida Radiance' on some harvest dates, with slightly higher sweetness and lower sourness. The average fruit size of 'Florida Brilliance' is approximately 20 grams, which is larger than 'Florida Radiance' but not as large as 'Florida127'. It also is very efficient to harvest due to its open yet robust plant and long stems (Figure 2).

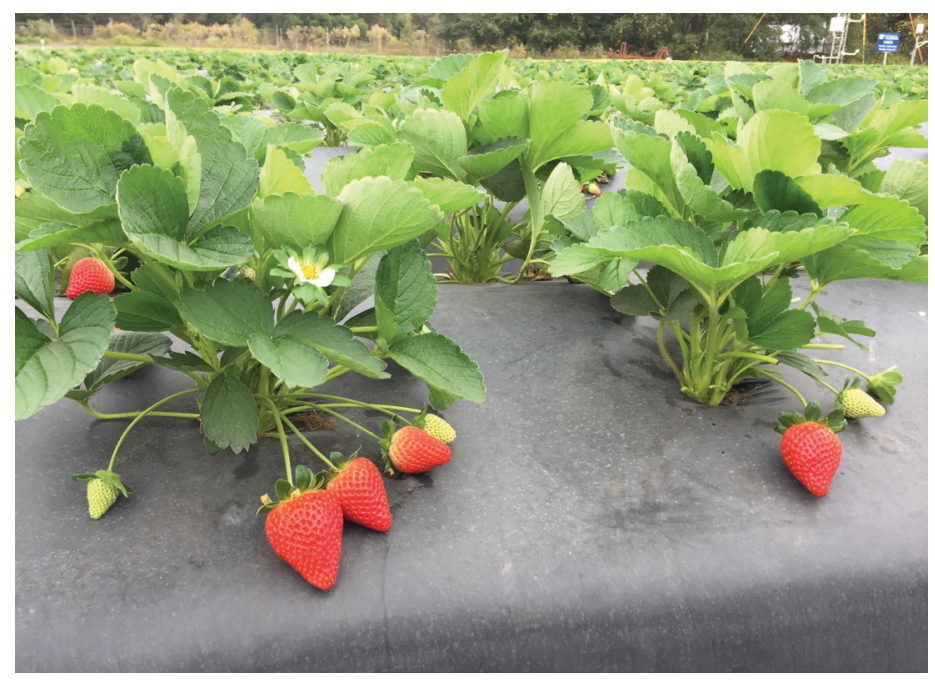

Figure 2. Plants and fruit of 'Florida Brilliance' at the Florida Strawberry Growers Association in Dover, Florida in December 2016.

Credits: Vance M. Whitaker, UF/IFAS

\section{Field Performance}

Early yields (late November through January) of 'Florida Brilliance' are the highest among the University of Florida cultivars. Not only is the onset of fruit slightly earlier, but the volume of yield in November and early December are noticeably larger than 'Florida Radiance' and somewhat larger than 'Florida127'. In an on-farm trial planted on Sept 25, 2016, 'Florida Brilliance' had a marketable yield of 812 flats $(6,496 \mathrm{lbs})$ per acre by the end of December compared to 540 flats $(4,320 \mathrm{lbs})$ per acre for 'Florida Radiance'.

Florida Brilliance' yields have outpaced other cultivars by the widest margin during seasons with unusually warm fall temperatures, indicating that this cultivar may be more resilient when exposed to heat stress and is more suitable for early planting than 'Florida Radiance' and 'Florida127'.

\section{Plant Establishment and Management}

'Florida Brilliance' can be established from bare-root or plug transplants available from certified nurseries. A typical in-row plant spacing of 15-16 inches is recommended, depending on the soil type and planting date. This is in contrast to 'Florida Beauty', which can be planted as close as 12 inches in-row. The traditional practice for bare-root, leaf-on transplants in Florida uses approximately 10 to 12 days of sprinkler irrigation for 8 to 12 hours/day, depending on air temperature and wind conditions. Growers are encouraged to reduce overhead irrigation to the minimum period possible without stressing transplants (see Disease Management section). For early transplanting dates during the last week of September, Florida growers may consider experimenting with black plastic mulch with a whiteon-black or metalized-on-black center stripe to reduce temperatures around the roots and crowns during and after establishment.

'Florida Brilliance' should be adaptable to a wide range of planting dates depending on soil type and other management practices. The ideal planting window for this cultivar in Hillsborough County, Florida is considered to be Oct 5 to 10 . On the sandiest soils (lowest organic matter), planting dates as early as Sept 25 have been effective, but planting this early on heavier soils may result in too much plant and runner growth. Figure 3 illustrates the recommended planting period relative to other cultivars in west-central Florida.

FL Brilliance
Sept 15
Figure 3. Recommended planting periods for University of Florida
strawberry cultivars in west-central Florida.
Fertilization ${ }^{\circledR}$ FL 127
Selection of the optimal fertilization program should be
based on the crop requirement and the natural fertility of
the soil. Field studies and observations suggest that 'Florida
Brilliance' has different fertility requirements compared
to 'Florida Beauty' and 'Florida Radiance'. For these two
varieties, plant growth is encouraged during the early


season with as much as 2-3 lbs N/acre/day after establishment, gradually tapering to as low as $0.75 \mathrm{lbs} \mathrm{N} / \mathrm{acre} /$ day. In contrast, 'Florida Brilliance' seems to require a shorter period of high $\mathrm{N}$ fertilization for establishment of no more than three weeks. Thereafter, no more than $1 \mathrm{lb} \mathrm{N} / \mathrm{acre} /$ day should be applied, or excess plant growth may occur. Growers should carefully monitor $\mathrm{N}$ levels throughout the season. For this reason, pre-plant $\mathrm{N}$ fertilization is not recommended.

Production of this cultivar in Florida, where deep, sandy soils with low organic matter are the norm, requires careful management of irrigation scheduling. During the early stages of growth in October and early November, when day temperatures are above $70^{\circ} \mathrm{F}$ and plants do not have a fully developed root system, it is suggested to provide one or two irrigation cycles per day totaling no more than $45 \mathrm{~min}$. This amount would vary depending on the nature of each season and soil type, and moisture in the top 6 inches of the beds should be monitored constantly using tensiometers or other moisture sensors. More information on irrigation scheduling is available at http://edis.ifas.ufl.edu/pdffiles/ CV/CV10700.pdf.

\section{Disease Management}

'Florida Brilliance' is moderately resistant to anthracnose fruit rot (caused by Colletotrichum acutatum), similar to 'Florida Radiance' (Seijo et al. 2011) (Table 1). More information about anthracnose can be found at http://edis. ifas.ufl.edu/pdffiles/PP/PP13000.pdf.

'Florida Brilliance' appears to have similar susceptibility to Botrytis fruit rot (caused by Botrytis cinerea) compared to 'Florida Radiance'. Fungicide applications for the control of Botrytis fruit rot should target the peak bloom periods. Switch $^{\mathrm{Tm}}$, Kenja ${ }^{\circledR}$, and Luna Tranquility ${ }^{\circledR}$ are currently the most effective fungicides for control of Botrytis fruit rot in Florida. High levels of fungicide resistance have been observed for other products including Topsin ${ }^{\circledR}$, Pristine $^{\circledR}$ and Scala ${ }^{\mathrm{rx}}$. To avoid an increase in fungicide resistance levels, multi-site fungicides (such as thiram and captan) should be utilized primarily. The number of systemic fungicide sprays should be reduced, and products with different modes of action should be rotated or tank-mixed. A web-based disease advisory system to aid growers on timing of fungicide applications for control of anthracnose and Botrytis fruit rots is available at http://agroclimate. org/tools/sas/fl. Following spray recommendations by the Strawberry Advisory System should help growers to reduce the number of fungicide applications without compromising disease control or yields. More information on the system is available at http://edis.ifas.ufl.edu/pdffiles/AE/ AE45000.pdf.

'Florida Brilliance' is also similar to 'Florida Radiance' in that it has moderate resistance to Podosphaera aphanis (powdery mildew). Quintec ${ }^{\circledR}$ and Torino ${ }^{\circledR}$ are currently the most effective fungicides for control of powdery mildew. Sulphur materials are also effective and help to manage an increase in fungicide resistance levels. DMI fungicides such as Procure ${ }^{\circledR}$ and Mettle ${ }^{\circledR}$ are also moderately effective, and may be rotated in a program.

Based on trials with inoculated plants, 'Florida Brilliance' is susceptible to crown and root rots caused by Phytophthora cactorum, though mortality is usually lower than for 'Florida Radiance'. Mefenoxam, the active ingredient in Ridomil Gold ${ }^{\circledR}$, is effective for reducing mortality in an infected crop. Due to concerns about the selection of pathogen resistance to mefenoxam, nurseries and fruit growers are encouraged to minimize the use of this product when possible. On the other hand, products containing potassium phosphite or potassium salts of phosphorus acid can be regularly applied as foliar sprays, and some are also labeled for drip application if infection is suspected.

Table 1. Disease resistance profile of 'Florida Brilliance' compared to 'Florida Radiance' $(R=$ resistant, $M R=$ moderately resistant, MS = moderately susceptible, $\mathrm{S}=$ susceptible, $\mathrm{HS}$ = highly susceptible).

\begin{tabular}{|l|l|c|c|}
\hline \multicolumn{1}{|c|}{ Disease } & \multicolumn{1}{c|}{ Pathogen } & FL Radiance & FL Brilliance \\
\hline Anthracnose fruit rot & Colletotrichum acutatum & MR & MS \\
\hline Angular leaf spot & Xanthomonas fragariae & S & MS \\
\hline Botrytis fruit rot & Botrytis cinerea & MS \\
\hline Charcoal rot & Macrophomina phaseolina & S & MR \\
\hline Colletotrichum crown rot & Colletotrichum gloeosporioides & HS & MR \\
\hline Phytophthora root rot & Phytophthora cactorum & MR \\
\hline Powdery mildew & Podosphaera aphanis & S \\
\hline
\end{tabular}


Because 'Florida Brilliance' has moderate resistance to Colletotrichum gloeosporioides (causal agent of Colletotrichum crown rot) and Macrophomina phaseolina (causal agent of charcoal rot), plant mortality in this cultivar is most likely to be from $P$. cactorum. However, to identify the causal agent of plant wilt and collapse, growers are encouraged to submit a sample to the UF Plant Diagnostic Lab at the UF/IFAS GCREC, where the pathogen will be isolated and identified and control recommendations provided.

\section{For Nursery Growers}

'Florida Brilliance' produces runners in the nursery at rates slightly lower than 'Florida Radiance' and similar to 'Florida127'. The foliage is more robust than 'Florida Radiance' and less prone to breakage. Nursery growers are strongly encouraged to prevent infections of Colletotrichum with regular sprays of captan and to address powdery mildew infections with sulfur products.

\section{Summary}

'Florida Brilliance' is a promising new cultivar for Florida. Based on research trials at the GCREC and in commercial fields, the following management recommendations can be made for this region:

1. Growers are encouraged to experiment with late September planting dates on lighter soils, though on heavier soils planting dates after Oct 5 may be most ideal.

2. In the first weeks after establishment of bare-root plants, high $\mathrm{N}$ rates are not required to maximize growth and yield as they are for 'Florida Radiance' and 'Florida Beauty. High $\mathrm{N}$ rates of approximately $2 \mathrm{lb} / \mathrm{acre}$ /day should be limited to 0 to 3 weeks, and thereafter rates should not exceed $1 \mathrm{lb} \mathrm{N} /$ acre/day.

3. Because of its excellent fruit firmness, 'Florida Brilliance' may be allowed to ripen one day longer than 'Florida Radiance' in the early season to maximize color and flavor without sacrificing shelf-life. However, in the late season in Florida when temperatures increase, management practices used for all cultivars to maximize fruit quality, such as lowering $\mathrm{N}$ rates and irrigation levels and harvesting fruit with less color, will also be important to maintain quality in 'Florida Brilliance'.
4. The primary disease susceptibility of this cultivar is to Phytophthora cactorum, while resistances to other root and crown rots are moderate to good. Thus, plant mortality in west-central Florida will most likely be due to this pathogen. The use of phosphite products is encouraged as a management option because there is low risk of resistance to these products.

\section{References}

Chandler, C. K., B. M. Santos, N. A. Peres, C. Joquand, A. Plotto, and C. A. Sims. 2009. “'Florida Radiance’ strawberry." HortScience. 44: 1769-1770.

Seijo, T., J. Mertely, V. M. Whitaker, and N. Peres. 2013. "Evaluation of strawberry cultivars and advanced selections for resistance to anthracnose and Botrytis fruit rots, 2012-13." Plant Dis. Mgmt. Rep. 8: SMF029. doi:10.1094/ PDMR05.

Whitaker, V. M., C. K. Chandler, N. A. Peres, M. C. N. Nunes, A. Plotto, and C. Sims. 2015. "Sensation" 'Florida127' Strawberry.” HortScience. 50: 1088-1091.

Whitaker, V. M., L. F. Osorio, N. A Peres, Z. Fan, M. Herrington, M. Cecilia do Nascimento Nunes, A. Plotto, and C. Sims. 2017. "Florida Beauty' Strawberry." HortScience. 52:1443-1447. 